\title{
A Review on Enhancement of Biogas Yield by Pre-treatment and addition of Additives
}

\author{
Dr. Prashant Baredar ${ }^{1, a}$, Dr.S Suresh ${ }^{2}$,Dr. Anil Kumar ${ }^{3}$ and Krishnakumar $\mathrm{P}^{4}$ \\ ${ }^{1}$ Associate Professor, Energy Centre, MANIT, Bhopal, India \\ ${ }^{2}$ Assistant Professor, Chemical Department, MANIT, Bhopal, India \\ ${ }^{3}$ Assistant Professor, Energy Centre, MANIT, Bhopal, India \\ ${ }^{4}$ Reasearch scholar, Energy Centre, MANIT, Bhopal, India
}

\begin{abstract}
Energy from biomass has been in use from historical days itself but biomass as energy source is not as popular as that of other renewable energy resources. Anaerobic digestion is commonly used to convert organic biomass into biogas. The main drawback of this technology is the long retention period and low efficiency. To tackle this problem pre-treatment and adding additives are best suitable options available. This paper reviews the different pre-treatment techniques and additives that can be used to improve the biogas (mainly methane) yield and to reduce the retention period of the process.
\end{abstract}

\section{Introduction}

Biogas is considered as a renewable energy can be produced from a variety of raw materials. Anaerobic digestion and fermentation can be used to generate biogas from biodegradable materials such as organic wastes, sewage, municipal waste, manure, plant residues, vegetable wastes and energy crops. Large amount of activated sludge wastes, containing organic and mineral substances, are produced by municipal and industrial plants. Waste sludge handling represents a bottleneck in industrial plants, due to environmental, social, economic and legal issues. Organic wastes are of natural origin that possesses biochemical features ensuring quick microbial decomposition at comparatively normal operating conditions.

Basically organic wastes generated today originate from industrial, agricultural and municipal sector. Municipal wastes are generated due to human biological and social activities contain large portion of organic materials. Agricultural wastes are common in livestock and food production which can be utilised for biogas production. Industrial wastes are the most difficult type of waste for biological treatment, depending of its content and origin. Many industries uses chemicals in their manufacturing processes to achieve better product quality and these chemicals are difficult to treat. Recently, organic waste has had a lot of attention, due to possibilities of energy that can be recovered from these wastes and to prevent their adverse effect on environment. Most of the organic wastes are in solid form which has moisture contain up to $90 \%$, so thermo chemical treatment of these wastes are difficult. Biodegradable organic waste can be treated in the presence or absence of

\footnotetext{
${ }^{\mathrm{a}}$ Corresponding author: prashant.baredar@gmail.com
}

air [1]. Aerobic process is called composting and anaerobic process is called digestion. Digestion is complicated, slow and expensive process, applicable only for selected raw materials. Recently, anaerobic digestion has become a widespread choice for biodegradable organic waste treatment around the world. It is well suited for organic wastes of high moisture content (over $80 \%$ ), yielding methane rich biogas.

\section{Anaerobic digestion}

Anaerobic digestion is a series of steps in which microorganisms break down biodegradable organic waste materials into biogas and slurry in the absence of free oxygen. Biogas is a mixture of different gases mainly methane, carbon dioxide and small traces of $\mathrm{H} 2 \mathrm{~S}, \mathrm{NH} 3$ and $\mathrm{H} 2$. The main features of digestion process are waste mass and volume reduction, biogas and nutrient-rich fertilizer productions. Table 1 shows typical solid and organic substance contents and biogas yields for most common organic wastes, treated with anaerobic digestion. The digestion process is divided into hydrolysis, acidogenesis, acetogenesis and methanogenesis.

Anaerobic digestion has a great future amongst the different renewable energy resources as well as in waste management technologies. However, the low overall bio digestion efficiency of the process and long retention periods (20-30 days) results in low efficiencies. In anaerobic digestion, the hydrolysis process is the raterestricting step in which soluble organic materials are converted to biogas are generated. Consequently, the biogas yield depends mainly on the biodegradability and hydrolysis rate of the digestion. Biogas production can be 
improved by pre-treatment of the organic wastes and adding additives to the slurry. During pre-treatment, both solubilisation of particulate matter and biological decomposition of organic long chain polymers to small chain monomers takes place ie. cell walls of the organic wastes are destroyed and extracellular polymeric substances are digested resulting in the conversion of organic material to a suitable form for easy digestion by acidogenic micro-organisms. Additive increases the microbial activity increasing the rate digestion process.

Table 1. Types of organic wastes and their biogas yield [3].

\begin{tabular}{|l|c|c|c|}
\hline \multicolumn{1}{|c|}{ Organic waste } & Total Solid[\%] & Volatile Solid [\%] & $\begin{array}{c}\text { Biogas yield } \\
{\left[\mathbf{m}^{\mathbf{3}} \mathbf{k g}^{-1} \mathbf{~ o f ~ V S ] ~}\right.}\end{array}$ \\
\hline Municipal organic waste & $15-30$ & $80-95$ & $0.5-0.8$ \\
\hline Municipal wastewater sludge & $3-5$ & $75-85$ & $0,3-0,5$ \\
\hline Brewery spent grain & $20-26$ & $80-95$ & $0.5-1.1$ \\
\hline Yeast & $10-18$ & $90-95$ & $0.5-0.7$ \\
\hline Fermentation residues & $4-8$ & $90-98$ & $0.4-0.7$ \\
\hline Rumen content (untreated) & $12-16$ & $85-88$ & $0.3-0.6$ \\
\hline Vegetable wastes & $5-20$ & $76-90$ & $0.3-0.4$ \\
\hline Grass cuttings (from lawns) & $20-37$ & $86-93$ & $0.7-0.8$ \\
\hline Grass silage & $21-40$ & $87-93$ & $0.6-0.8$ \\
\hline Corn silage & $20-40$ & $94-97$ & $0.6-0.7$ \\
\hline Straw from cereals & $\sim 86$ & $89-94$ & $0.2-0.5$ \\
\hline Cattle manure (liquid) & $6-11$ & $68-85$ & $0.1-0.8$ \\
\hline Cattle excreta & $25-30$ & $75-85$ & $0.6-0.8$ \\
\hline Pig manure (liquid) & $2-13$ & $77-85$ & $0.3-0.8$ \\
\hline Pig excreta & $20-25$ & $75-80$ & $0.2-0.5$ \\
\hline Chicken excreta & $10-29$ & $67-77$ & $0.3-0.8$ \\
\hline Sheep excreta & $18-25$ & $80-85$ & $0.3-0.4$ \\
\hline Horse excreta & $25-30$ & $70-80$ & $0.4-0.6$ \\
\hline Whey & $4-6$ & $80-92$ & $0.5-0.9$ \\
\hline
\end{tabular}

Table 2. Reviews on different pre-treatment methods to enhance AD using various substrates.

\begin{tabular}{|c|c|l|}
\hline Substrate & Pretreatment & \multicolumn{1}{|c|}{ Conclusions } \\
\hline OFMSW & $\begin{array}{c}\text { All pretreatment } \\
\text { methods }\end{array}$ & $\begin{array}{l}\text { Physical pretreatments are widely applied for OFMSW, whereas other } \\
\text { methods are not spread at industrial level }\end{array}$ \\
\hline $\begin{array}{c}\text { All organic } \\
\text { substrates } \\
\text { methods }\end{array}$ & $\begin{array}{c}\text { All pretreatment } \\
\text { The most popular pretreatment methods are thermal and ultrasonic for } \\
\text { WWTP sludge, chemicalfor lignocellulosic substrates, and mechanical } \\
\text { for OFMSW }\end{array}$ \\
\hline $\begin{array}{c}\text { Lignocellulosic } \\
\text { substrates }\end{array}$ & $\begin{array}{c}\text { Thermal, thermo- } \\
\text { chemical, chemical }\end{array}$ & $\begin{array}{l}\text { Thermal pretreatments as well as lime and ammonia based chemical } \\
\text { methods are more effectivein improving the digestibility of } \\
\text { lignocellulosic substrates }\end{array}$ \\
\hline $\begin{array}{c}\text { Pulp \& paper } \\
\text { sludge }\end{array}$ & $\begin{array}{c}\text { Thermal, thermo- } \\
\text { chemical, chemical }\end{array}$ & $\begin{array}{l}\text { Pretreatments could result in reduced HRT, increased methane } \\
\text { production, and reduced sludge size }\end{array}$ \\
\hline $\begin{array}{c}\text { WWTP sludge } \\
\text { Ultrasound, chemical, } \\
\text { and thermal }\end{array}$ & $\begin{array}{l}\text { Pretreatments result in enhanced biogas production (30-50\%) } \\
\text { Thermal, thermo- } \\
\text { chemical, and chemical }\end{array}$ & $\begin{array}{l}\text { The effect of pretreatment methods depends on the characteristics of } \\
\text { sludge and the intensity ofthe method. Pretreatments could yield a } \\
\text { better digestate with high recoverable nutrients }\end{array}$ \\
\hline WWTP sludge
\end{tabular}

\section{Pre-treatment}

Different pre-treatment techniques such as thermal, chemical, biological, mechanical and their combinations are reviewed in this paper. Pre-treatment techniques are used to make the organic matter become more accessible to anaerobic microorganisms. This process improves the overall digestion efficiency and the degree of digestion, reducing retention time and increasing methane production rates [3]. The paper will provide a sequence of literature reviews about optimum conditions to obtain enhanced biogas production in various pre-treatments techniques. Table 2 shows the important findings of different researches on pre-treatment of various biomasses.

\subsection{Thermal pre-treatment}

It is well known for many years that thermal pretreatment can improve the degradability of organic wastes. While the lipids and the carbohydrates of the wastes are easily degradable, the proteins are protected by cell walls from hydrolysis. Heat supplied during thermal pre-treatment breaks the chemical bonds of the cell wall, thus makes the protein content easily accessible for biological digestion. Maximum bio digestibility, in 
percentage, means the maximum percentage of substrate chemical oxygen demand (COD) that can be converted to methane, was calculated by El-Mashad et al [4]. Effect of thermal pre-treatment is studied in a wide range of temperatures ranging from 60 to $270{ }^{\circ} \mathrm{C}$. In practice, the optimum temperature for the pre-treatment process is $160-180^{\circ} \mathrm{C}$ and treatment time between 30 to $60 \mathrm{~min}$. Pressure associated with it may vary from 600 to $2500 \mathrm{kPa}$. Various researches on thermal pre-treatment have been conducted to verify this conclusion. Bougrier et al compared the thermal pre-treatment $\left(130^{\circ} \mathrm{C}, \mathrm{pH}=10\right.$, $150^{\circ} \mathrm{C}$ and $170^{\circ} \mathrm{C}$ during $\left.30 \mathrm{~min}\right)$ performance of waste activated sludge obtained from urban wastewater plants with untreated sludge. The results suggested that there was positive effect on solubilisation rates and methanization rate when thermal pre-treatment was performed [5].

Haug et al. worked on thermal treatment at low temperatures in order to improve digestibility of the waste and it also helped them to avoid the problems that occurred with high temperature thermal pre-treatment.

Their experiments showed that the effect on digestibility of activated sludge was high at $175^{\circ} \mathrm{C}$. The anaerobic digestion of the thermally pre-treated biomass at this temperature resulted in an increased methane production of $60-70 \%$ and higher temperatures led to decrease in methane production [6].

\subsection{Chemical pre-treatment}

Chemical pre-treatment is an efficient and cost-effective method to hydrolyze the cell walls and thus increase solubility of the organic matter contained within the cells. According to different principles, chemical treatment methods can be classified into acid and alkaline oxidation. The most frequent oxidative methods are ozonation and peroxidation.

\subsection{Colour illustrations}

You are free to use colour illustrations for the online version of the proceedings but any print version will be printed in black and white unless special arrangements have been made with the conference organiser. Please check with the conference organiser whether or not this is the case. If the print version will be black and white only, you should check your figure captions carefully and remove any reference to colour in the illustration and text. In addition, some colour figures will degrade or suffer loss of information when converted to black and white, and this should be taken into account when preparing them.

\subsubsection{Ozonation}

Ozone is a strong cell-lytic agent, which can destroy the microorganisms present in activated sludge and oxidize the organic substances released from the cells [7]. Among the techniques to disintegrate sludge, ozonation of sludge is one of the effectual way and yields the utmost degree of disintegration. Ozonation process changes the characteristics of the sludge greatly. The sludge biodegradation is affected by the amount of ozone. Several researchers have investigated the impact of ozone amount on sludge biodegradation. Ozonation treatment has two counter effects: degradation of molecules and cell structures which is responsible for the increase in biogas production and oxidation of organic molecules which is responsible for the decreases in biogas production [10]. According to Weemaes et al. the biogas yield increased by $80 \%$ with ozone treatment of $0.1 \mathrm{~g}$ $\mathrm{O} 3 / \mathrm{g}$ COD; the effect was not evident at higher concentration of ozone [7]. A review of studies on the combination of ozonation with activated sludge process was proposed by $\mathrm{Chu}$ et al [8].

\subsubsection{Peroxidation}

Several peroxidation techniques, including the popular Fenton peroxidation and novel reactions of peroxymonosulphate (POMS) and dimethyldioxirane (DMDO), can achieve a transformation of available COD into soluble BOD enhancing the biogas production. Fenton pre-treatment disintegrates extracellular polymeric substances and breaks cell walls, releasing intracellular water. Hence increasing the soluble COD and BOD in the sludge water. Low $\mathrm{pH}$ value required is the major disadvantage of this method. Dewil et al. studied biogas generation by treating sludge with Fenton peroxidation, DMDO and POMS techniques on laboratory scale. The results showed a maximum increase of $75 \%$ with Fenton, while the biogas production became twice by PMOS and by DMDO method biogas production was increased by a factor of 2.5[9].

\subsection{Thermo-chemical pre-treatment}

Alkali treatment combined with thermal treatment is called thermochemical treatment. There is no agreement on the efficiency of this method. Kim et al. showed that the order of effectiveness in sludge solubilization was $\mathrm{NaOH}>\mathrm{KOH}>\mathrm{Mg}(\mathrm{OH}) 2$ and $\mathrm{Ca}(\mathrm{OH}) 2$, whereas Penaud et al. demonstrated that pre-treatment with $\mathrm{KOH}$ was more efficient than using $\mathrm{NaOH}$ and observed no effect on the biodegradability [10]. Haug et al. determined a decrease in biodegradability of $60 \%[6]$. Tanaka et al. showed that thermo chemical pre-treatment significantly raised the biodegradability upto $230 \%$. It's noted that thermo chemical method gives the best result compared with thermal, chemical, ultrasonic methods under same conditions. Valo et al. tested the COD removal rates and biogas production under two conditions (thermal treatment at $170^{\circ} \mathrm{C}$ and thermo-chemical at $130^{\circ} \mathrm{C}$ with $\mathrm{PH}=10$ for $30 \mathrm{~min}$ ). They found that the COD removal rates were significantly increased compared with the untreated raw sludge, being $71 \%$ and $60 \%$ of raw sludge COD, respectively, while the biogas generations were increased by $54 \%$ and $74 \%$ [11].

\subsection{Mechanical pre-treatment}


Mechanical pre-treatment favours solubilisation of particulate matters in liquid state which in turn improves the yield of the biomass. In general, in mechanical pretreatment the most often techniques used are ultrasonic pre-treatment, grinding and high pressure homogenization. By these methods, the aim is to increase the degradability of organic matters by disrupting the flocs and/or lysing the bacterial cells.

\subsubsection{Ultrasonic pre - treatment}

Ultrasonication is an effective and promising method to improve the biodegradability of the sludge. This method has several inherent advantages such as efficient sludge disintegration ( $>95 \%$ ), improvement in biodegradability and bio solids quality, increase in methane production, reduction in retention time, sludge reduction and energy recovery [12]. This method enhances the sludge digestibility by disrupting the chemical, physical and biological properties of the sludge. Ultrasonic treatment accelerates the hydrolysis reactions by disrupting cell walls. The bacterial cells are divided by pressure waves and cavitations produced by ultrasonic generator leading to extraction of intracellular organic elements. The disruption of sludge particles obtained from ultrasonication treatment will boost subsequent acidogenesis, acetogenesis and methanogenesis reactions leads to an enhanced methane production and reduction of sludge volume [13]. Wang et al. showed that the methane generation was increased by $12 \%, 31 \%, 64 \%$ and $69 \%$ with corresponding ultrasonic pre-treatment of 10minutes, 20 minutes, 30 minutes and 40 minutes, respectively. The optimum pre-treatment for enhancing the methane generation should be approximately $30 \mathrm{~min}$.

\subsubsection{Grinding}

One dominant pre-treatment technique is the wet milling, which is more of a grinding method. Wet milling uses small beads to break cell walls, the size of the beads used are thus critical for maximal sludge disintegration. Of several milling devices, the ball mill using small diameter $(0.2-0.275 \mathrm{~mm})$ balls has the best performance [13]. During grinding sludge is pressed through a conical or cylindrical space with shear-stresses high enough to break the bacterial cell walls.

\subsubsection{High pressure homogenizer}

One of the most frequently used methods on large-scale is high pressure homogenization, compressing the sludge to a pressure of $60 \mathrm{MPa}$ [1]. The compressed suspension is then depressurized using a valve and projected against an impaction ring at very high speed. The cells are hereby subjected to turbulence, cavitations and shear stresses, resulting in cell disintegration. Lack of available literatures on mechanical pre-treatment, the methods mentioned above is not comprehensive. However, it's seen that their efficiency of improving anaerobic digestion of waste activated sludge is rather lower than other methods [14].

\section{Additives}

Organic as well as inorganic chemicals can be added to improve methane gas production. Additives can increase microbial activity under different environmental conditions. Some organic substances are naturally available [15]. Usually additives are classified into organic and inorganic additives.

\subsection{Inorganic Additives}

There are many inorganic additives for example, iron salt that enhances gas production. Different salts were added to the slurry at different concentrations; FeSO4 was added at $50 \mathrm{mM}, \mathrm{FeCl} 3$ at $70 \mu \mathrm{M}$. The addition of magnesium and calcium salts increased methane generation and avoided slurry foaming [15]. Malik et al. obtained an increased biogas production by $8-11 \%$ adding urea and diammonium phosphate to the sludge. Kumar et al.(1987) experiment on commercial charcoal Darco G-60 resulted in $17 \%$ and $34.7 \%$ increase in biogas yield in batch and semi continuous digesters, respectively. Nickel ions increase the methane production by $54 \%$. Nickel was found to enhance the production up to $5 \mathrm{ppm}$. The optimum range appeared to be at $2.5 \mathrm{ppm}$ in a water hyacinth-bovine waste substrate. The increase in biogas is due to the activity of nickel dependent metallo-enzymes involved in digestion [16]. Eosin blue dye at a concentration of $0.1 \mu \mathrm{M}$ increased the biogas by $25-35 \%$ when mixed to manure slurry [17].

\subsection{Organic Additives}

Organic additives can maintain favourable conditions for increased gas production in anaerobic digestion. These conditions include: inhibition of acetogenesis and methanogenesis, $\mathrm{pH}$, etc. Powdered leaves of some plants such as gulmohar, leucacenaleucocephala, acacia auriculiformis, dalbergiasisoo and eucalyptus tereticonius have found to improve biogas yield by 18 $40 \%$ [15]. Enhanced biogas production due to organic additives is due to the adsorption of substrate on the surface of the additive. Plant residues treated with $1 \%$ $\mathrm{NaOH}$ for 7 days combined with slurry manure at a weight ratio of 1:1 showed a twice increase in biogas production [17].

Tomato plant wastes when added to rabbit wastes improved methane production when the amount of tomato waste is more than $40 \%$ [18]. Plant waste like rice straw, corn stalks, cotton stalks and wheat straw when mixed with cattle manure increased gas production by 10 $80 \%$. Addition of bean seeds, guar, black gram and guar gum at a rate of $1500 \mathrm{ppm}$ in the biodegradation of mango processing wastes increased methane production significantly. The addition of organic and inorganic substances to slurry waste increases the efficiency of anaerobic digestion and methane gas production. Some additives can increase the gas production even by $80 \%$. Most of these options are easy and economically viable. 


\section{Conclusions}

This paper reviewed various methods which can be used to minimize these drawbacks of anaerobic digestion. Pretreatment of the waste and adding additives to the sludge are effective methods reduces the retention period and increases the digestion efficiency. Effectiveness of different techniques is discussed in the paper. The change in biogas production is different for different techniques. The increase in the biogas production in percentage by various techniques is summarized in the Table 3. It can be seen that mechanical pre-treatment methods requires high capital investment and are energy intensive. Thermal and thermo chemical methods require high temperatures to achieve better results. Cost of oxidative methods is high and requires low $\mathrm{pH}$. However it appears that taking into account the increased financial requirements of sludge disposal, the operational cost and the investments required for sludge, ozonation may be the best option available due to their decreased operational costs for sludge treatment and disposal.

Table 3. Percent increase in biogas production by different methods.

\begin{tabular}{|c|c|c|c|}
\hline \multicolumn{3}{|c|}{ Method } & $\begin{array}{l}\text { Percentage } \\
\text { increase in } \\
\text { methane } \\
\text { production } \\
(\%)\end{array}$ \\
\hline \multirow[t]{5}{*}{ Pre-treatment } & \multicolumn{2}{|l|}{ Thermal } & $60-70$ \\
\hline & \multirow[t]{2}{*}{ Chemical } & Ozonation & 80 \\
\hline & & Peroxidation & $75-150$ \\
\hline & \multicolumn{2}{|c|}{ Thermo-chemical } & $75-230$ \\
\hline & \multicolumn{2}{|c|}{ Ultrasonic } & $12-69$ \\
\hline \multirow{2}{*}{$\begin{array}{l}\text { Addition of } \\
\text { additives }\end{array}$} & \multicolumn{2}{|l|}{ Organic } & $10-80$ \\
\hline & \multicolumn{2}{|l|}{ Inorganic } & $8-150$ \\
\hline
\end{tabular}

\section{References}

1. S. Umesh, S. Swati, B. Kansingh and V. Mayank, Activated Sludge Treatment Process to Increase Bio Gas Production-A Need of Present Energy Crisis Scenario, (2013)

2. Zupančič, D. Gregor, and V. Grilc, Management of Organic Waste, 1-28 (2012)
3. Ariunbaatar, Javkhlan, A. Panico, G. Esposito, F. Pirozzi, and Piet NL Lens, Applied energy 123, 143156 (2014)

4. El-Mashad, M. Hamed, G. Zeeman, Wilko KP van Loon, Gerard PA Bot, and G. Lettinga, Bioresource technology 95, 191-201 (2004)

5. Bougrier, Claire, J-P. Delgenes, and H. Carrere. Process Safety and Environmental Protection 84, 280-284 (2006)

6. Haug, T. Roger, D. C. Stuckey, J. M. Gossett, and P. L. McCarty, Journal (Water Pollution Control Federation) 73-85 (1978)

7. S. Chu, Libing, S. Yan, X. Hui Xing, X. lin Sun, and B. Jurcik, Water Research 43, 1811-1822 (2009)

8. Yeom, I.T., Lee, K.R., Lee, Y. H., Ahn, K. H. \& Lee, S. H., Water Science and Technology 46, 421425(2000)

9. Kim, Jeongsik, C. Park, Tak-Hyun Kim, M. Lee, S. Kim, S. Wook Kim, and J. Lee, Journal of bioscience and bioengineering 95, 271-275 (2003)

10. Penaud, V., J. P. Delgenes, and R. Moletta, Enzyme and microbial technology 25, 258-263 (1999)

11. Tanaka, Shuzo, Toshio Kobayashi, KenichiKamiyama, and Ma Lolita N. SigneyBildan. Water Science and Technology 35, 209-215 (1997)

12. Pilli, Sridhar, PuspenduBhunia, Song Yan, R. J. LeBlanc, R. D. Tyagi, and R. Y. Surampalli. Ultrasonics sonochemistry 18, 1-18 (2011)

13. W. Qunhui, M. Kuninobu, K. Kakimoto, I. Hiroaki, and Y. Kato, Bioresource technology 68, 309-313 (1999)

14. Baier, Urs, and P. Schmidheiny, Water Science and Technology 36, 137-143 (1997)

15. A. Yadvika, A. Santosh, T. R. Sreekrishnan, KohliSangeeta, and R. Vineet, Bioresource Technology, (2004)

16. Geeta, G. S., K. SlJagadeesh, and T. K. R. Reddy, Biomass 21, 157-161 (1990)

17. Dar, Gh Hassan, and S. M. Tandon. Biological wastes 21, 75-83 (1987)

18. D. Trujillo, J. F. Perez, and F. J. Cebreros. Bioresource technology 45, 81-83 (1993) 